\title{
Współczesne tendencje w obszarze ochrony konsumentów na rynku usług finansowych z uwzględnieniem regulacji instytucji ochrony konsumentów: Rzecznika Finansowego i Prezesa Urzędu Ochrony Konkurencji i Konsumentów ${ }^{1}$
}

\section{Wprowadzenie}

Osoba korzystająca z usług finansowych, niezależnie od tego, czy jest osobą fizyczna, czy osobą prawną, może w razie sporu z instytucją finansową wszcząć postępowanie cywilne w sądzie ${ }^{2}$. Jednak biorąc pod uwagę sytuację faktyczną i ekonomiczną pewnych grup osób, zostały stworzone takie rozwiązania prawne, które ułatwiają osobom fizycznym dochodzenie swoich praw. Stworzono bowiem instytucje, które mają za zadanie wspieranie osób na różnych etapach postępowania, a nawet przed jego wszczęciem, niezależnie od postępowania sądowego. Przykładem może być tu powiatowy rzecznik konsumentów, który ma przede wszystkim za zadanie doradzać konsumentom, udzielać informacji prawnej. Niektóre z instytucji ochrony konsumentów mają charakter bardziej uniwersalny i wspierają ich w każdej sprawie, inne to wyspecjalizowane instytucje, które zajmują się sprawami o ograniczonym zakresie przedmiotowym.

* Sofya Chashchina, Uniwersytet im. Adama Mickiewicza w Poznaniu, https://orcid. org/0000-0002-7423-9351.

${ }^{1}$ Artykuł naukowy jest wynikiem pracy w projekcie Szkoła orłów pt. Ochrona konsumenta ustug finansowych w prawie polskim i europejskim realizowanym na Wydziale Prawa i Administracji Uniwersytetu im. Adama Mickiewicza w Poznaniu.

${ }^{2}$ M. Sieradzka, Pozew grupowy jako instrument prywatnoprawnej ochrony interesów konsumentów z tytułu naruszenia reguł konkurencji, Warszawa 2012, s. 386. 
Powyższe skłania do spojrzenia na ochronę, której udziela się uczestnikom rynku usług finansowych, nie tylko z perspektywy przepisów materialnoprawnych, lecz także regulacji kształtujących instytucje chroniące konsumentów. Nawet w samej Unii Europejskiej (UE), nie sięgając dalej do praktyki światowej, wyróżnia się różnorodne podmioty, którym przypisuje się ochronę konsumentów. Oprócz instytucji, których głównym zadaniem jest ochrona konsumenta, w spisie znajdują się również banki centralne państw członkowskich UE3. Celowe wydaje się wobec tego dokonanie analizy systemowej wskazanych wyżej instytucji i spojrzenie pod kątem ochrony udzielanej podmiotom słabszym na rynku finansowym niezależnie od ram organizacyjnych, w których podmioty te występują.

Do wielości instytucji dochodzi też problem określenia, kto jest podmiotem chronionym. Brak jednolitego nazewnictwa podmiotu, który według przepisów uprawniony jest do korzystania ze specyficznych ochronnych rozwiązań prawnych, skłania do rozważenia kolejnego aspektu, mianowicie: czy sposób określenia i zdefiniowania podmiotu $\mathrm{w}$ aktach prawnych ma istotne znaczenie dla korzystania $\mathrm{z}$ ochrony prawnej przez tę osobę. Zatem czy istnieje rzeczywista różnica pomiędzy konsumentem a klientem, czy obecnie mamy do czynienia tylko z synonimicznymi określeniami prawnymi, które w swojej istocie mają na celu ochronę jednolitego kręgu podmiotów?

To pytanie badawcze staje się kluczowe także ze względu na liczne głosy optujące za włączaniem kolejnych grup podmiotów do obszaru "jurysdykcji" instytucji ochrony konsumentów czy, również ustawowo, klientów na rynku usług finansowych ze względu na ich cechy szczególne i warunki, na których są zmuszeni uczestniczyć w transakcjach na tym rynku, a w ślad za tymi głosami idą zmiany legislacyjne. Są to głosy nie tylko badaczy, lecz również organów państwowych. Tak m.in. stwierdził Rzecznik Małych i Średnich Przedsiębiorców (Rzecznik MSP): „zasadne byłoby również rozszerzenie katalogu przedsiębiorców, którym (Rzecznik Finansowy) mógłby udzielać wsparcia", a byłyby to, w rozumieniu Rzecznika MSP, mikroprzedsiębiorstwa ${ }^{4}$.

${ }^{3}$ Instytucje ochrony konsumenta na stronie internetowej Europejskiego Urzędu Nadzoru Bankowego, https://www.eba.europa.eu/consumer-corner/national-competent-authorities-for-consumer-protection (dostęp: 26 IV 2021).

${ }^{4}$ Rzecznik MSP, Pismo do Podsekretarza Stanu w Ministerstwie Finansów - pismo zawierające uwagi Rzecznika MSP do projektu ustawy o rozpatrywaniu reklamacji i sporów klientów podmiotów rynku finansowego (UC125) z prośbą o ich uwzględnienie, 
Od wymiaru instytucjonalnego ochrony konsumenta zależy efektywność i sprawność działań nakierowanych na wyrównywanie pozycji konsumenta na rynku. Akcent stawiany na wymiar instytucjonalny wynika przede wszystkim z funkcji, które pełni ochrona konsumenta. Między innymi edukacja konsumencka - jako jedna z form tej ochrony - bez rozbudowanej sieci instytucjonalnej jest bardzo utrudniona.

Nie można pominąć również tej okoliczności, że konsument usług oferowanych na rynku finansowym pośrednio podlega przepisom publicznoprawnym, które regulują działalność przedsiębiorców finansowych. Od kształtu tych przepisów w pewnej mierze zależeć będzie sytuacja konsumenta. Mowa tu przede wszystkim o dokumentach wydawanych przez organy nadzorcze rynku finansowego, które nie są aktami prawnymi powszechnie obowiązującymi, ale są tak zwanym soft law, których treść jest wiążąca tylko dla instytucji finansowych, czyli podmiotów podlegających nadzorowi. Dla przykładu dokumenty te wprowadzają dodatkowe wymogi formalne, jak również wymogi zbadania rzeczywistych potrzeb klienta, które określane są także przez akty prawa powszechnie obowiązującego o charakterze nadzorczym. Zatem w praktyce wpływ rekomendacji może być porównywalny z mocą aktu prawnego, ich postanowienia mogą między innymi wydłużać proces otrzymania kredytu czy ubezpieczenia, a także wymagać od klienta podania informacji z zakresu własnej sytuacji materialnej i życiowej, która - na przykład przed wydaniem danych rekomendacji przez Komisję Nadzoru Finansowego - nie była wymagana ${ }^{5}$.

Poniższe rozważania dotyczą kluczowych polskich instytucji ochrony konsumenta rynku finansowego: Rzecznika Finansowego (RzF) oraz Prezesa Urzędu Ochrony Konkurencji i Konsumentów (Prezesa UOKiK), a także zmian w zakresie ich funkcjonowania. Jako rynek finansowy jest rozumiany obszar, w którym odbywają się transakcje pomiędzy konsumentem a instytucją finansowa, na przykład bankiem, ubezpieczycielem czy biurem maklerskim. Poza krajowymi regulacjami są przywołane także akty prawa unijnego, by z perspektywy unijnego prawodawcy pokazać, jak kształtuje się wizja odpowiedniej, efektywnej

https://rzecznikmsp.gov.pl/wp-content/uploads/2020/10/WPL.620.2020.\%C5\%81P. pdf (dostęp: 5 V 2021).

${ }^{5}$ Przykładem może być tu Rekomendacja S dotycząca dobrych praktyk w zakresie zarządzania ekspozycjami kredytowymi zabezpieczonymi hipotecznie (Warszawa, 2019) wydana przez KNF, która jako jeden z obszarów objętych dokumentem wskazuje relacje z klientami. 
ochrony konsumenta. Zastosowaną metodą badawczą jest metoda dogmatycznoprawna. Analizę oparto na przepisach dotyczących ochrony konsumenta oraz funkcjonowania rynku finansowego. Wykorzystany został również dorobek doktryny.

\section{Pojęcie klienta rynku finansowego}

Na początku rozważań warto poruszyć kwestie terminologiczne. Różnie tłumaczy się pojęcia konsumenta i klienta w zależności od rodzaju tekstu źródłowego i kontekstu, w jakim są użyte. Z jednej strony, zarówno w doktrynie, jak i w tekstach aktów prawnych, nie ma jednolitości w postrzeganiu konsumenta i klienta, z drugiej zaś strony nie sposób zanegować stanowiska, w świetle którego pojęcia te są utożsamiane. Rozróżnić należałoby pojęcia używane w doktrynie, a także ich znaczenie, od tych stosowanych w aktach prawnych. Pojemność tych definicji jest często rozszerzana w literaturze poprzez wysuwane postulaty włączenia do grona podmiotów chronionych przez instytucje ochrony konsumentów tych podmiotów, które zgodnie z definicją ustawową nie są zaliczane do konsumentów, ale są tak nazwane i zdefiniowane w innych aktach prawnych. E. Rutkowska-Tomaszewska wskazuje jako stan pożądany objęcie ochroną konsumencką mikro- i małych przedsiębiorców na rynku, gdyż "mogą w niektórych przypadkach (...) działać «nie w pełni» profesjonalnie, tzn. nie jak przedsiębiorcy, lecz jak «zwykłe» osoby fizyczne ${ }^{\prime \prime}$. Za tym postulatem przemawiać może fakt, że definicje unijnych programów wieloletnich ochrony konsumenta akcentują właśnie element funkcjonalny, czyli „fakt zaopatrzenia lub korzystania z dóbr i usług na użytek nieprofesjonalny"7. Jednak takie podejście sprawiać może wiele komplikacji i budzić wiele nieporozumień: kto jest chroniony, a kto nie na gruncie ustaw regulujących działanie RzF i Prezesa UOKiK.

W praktyce legislacyjnej, gdy do grona podmiotów chronionych, zdefiniowanych w aktach prawnych, wprowadzane są kolejne podmioty, ustawodawca nie rozbudowuje dodatkowo już istniejącej definicji ustawowej ani nie tworzy nowej. Zamiast tego wprowadza oddzielne przepisy, w których nadaje się podmiotom dodatkowe uprawnienia.

${ }^{6}$ E. Rutkowska-Tomaszewska, Ochrona prawna klienta na rynku ustug bankowych, Warszawa 2013, s. 108.

${ }^{7}$ E. Łętowska, Prawo umów konsumenckich, Warszawa 2002, s. 48. 
Za przykład tej tendencji może posłużyć jedna z ostatnich nowelizacji w obszarze ochrony konsumenta. Niektórymi prawami konsumenta zostały objęte osoby fizyczne dokonujące transakcji z przedsiębiorca, które to transakcje są bezpośrednio związane z ich działalnością gospodarczą. Warunkiem jest jedynie brak charakteru zawodowego zawartej pomiędzy stronami umowy. Novum wprowadziły przepisy dwóch ustaw: Ustawy z dnia 23 kwietnia 1964 r. Kodeks cywilny w art. $385^{5}$ i art. 556 (od 1 stycznia 2021 r.) oraz Ustawy z dnia 30 maja 2014 r. o prawach konsumentów ${ }^{8} \mathrm{w}$ art. 38a (od 1 czerwca 2020 r.). Są to przepisy dotyczące niedozwolonych klauzul umownych, rękojmi oraz prawa odstąpienia od umowy. Ochroną nie objęto umów dotyczących usług finansowych zawartych na odległość, choć ich specyfika z gospodarczego punktu widzenia mogłaby prowadzić do większych strat w majątku jednoosobowych przedsiębiorstw w przypadkach czynów nieuczciwych podejmowanych przez przedsiębiorców finansowych niż w przypadku korzystania z innego rodzaju usług.

Stosowane w ustawach pojęcia określające podmioty korzystające z usług finansowych - jak zauważono wyżej - różnią się w zależności od rodzaju aktu prawnego. Jako przykład wskazać można użyte w Ustawie z dnia 29 lipca 2005 r. o obrocie instrumentami finansowymi ${ }^{9}$ pojęcie klienta detalicznego, stosowane w odniesieniu do podmiotów, które są chronione pośrednio poprzez odpowiednie regulacje dotyczące usługodawców finansowych, innymi słowy nakładające na przedsiębiorców finansowych pewne obowiązki. Ochrona praw takich usługobiorców jest sprawowana przez organy nadzorcze, np. Komisję Nadzoru Finansowego (KNF). Odmienne pojęcia występują w aktach prawnych precyzyjnie wskazujących krąg podmiotów, które mogą bezpośrednio uzyskać pomoc instytucji ochrony konsumentów usług finansowych konsument i klient.

Pierwszym z pojęć użytych dla określenia podmiotu chronionego jest konsument. Pojęcie to w prawniczym języku najczęściej wskazuje na słabszą stronę $\mathrm{w}$ umowie $\mathrm{z}$ profesjonalistą. Określenie to wywodzi się $\mathrm{z}$ nauki ekonomii ${ }^{10} \mathrm{i}$ stało się trzonem szeroko pojętego prawa

${ }^{8}$ Tekst jedn. Dz.U. 2020, poz. 287.

${ }^{9}$ Tekst jedn. Dz.U. 2021, poz. 328 ze zm.

${ }^{10}$ A. Nadolska, Konsument $i$ klient na rynku ustug finansowych. Problem zakresu podmiotowego ochrony na rynku finansowym, w: Ochrona konsumenta na polskim i międzynarodowym rynku finansowym, pod red. J. Monkiewicza, E. Rutkowskiej-Tomaszewskiej, Warszawa 2019, s. 70. 
konsumenckiego. Definicję konsumenta określa Ustawa z dnia 23 kwietnia 1964 r. Kodeks cywilny ${ }^{11}$, która w art. $22^{1}$ stanowi, iż za konsumenta uważa się osobę fizyczną dokonującą z przedsiębiorcą czynności prawnej niezwiązanej bezpośrednio z jej działalnością gospodarczą lub zawodową. W Ustawie z dnia 16 lutego 2007 r. o ochronie konkurencji i konsumentów (ustawa uokik) ${ }^{12}$, która reguluje funkcjonowanie Prezesa Urzędu Ochrony Konkurencji i Konsumentów, stosuje się właśnie cywilistyczną definicję konsumenta. Można wymienić też inne ustawy, w których użyto terminu konsument: Konstytucja Rzeczpospolitej Polskiej $^{13}$, która w art. 76 postuluje ochronę konsumentów przez władze publiczne, oraz ustawa Prawo przedsiębiorców ${ }^{14}$, która wyznaczając model przedsiębiorcy w art. 9, wskazuje konieczność respektowania interesów innych przedsiębiorców oraz interesów konsumentów.

Drugim określeniem użytym przez ustawodawcę jest klient - w Ustawie z dnia 5 sierpnia 2015 r. o rozpatrywaniu reklamacji przez podmioty rynku finansowego i o Rzeczniku Finansowym ${ }^{15}$ (ustawa o RzF). Definicja klienta w art. 2 pkt 1 ustawy o RzF nie ma charakteru opisowego (jak w przypadku konsumenta), natomiast ma formę wyliczenia. W rozumieniu ustawy o RzF klientem jest między innymi osoba fizyczna dochodząca roszczeń z tytułu umowy ubezpieczenia, członek funduszu emerytalnego czy też osoba uprawniona. Podstawowym kryterium, które powinien spełnić podmiot stosunku z przedsiębiorcą finansowym, jest przymiot osoby fizycznej. W swoim sprawozdaniu z działalności za 2020 r. Rzecznik Finansowy wskazuje jako jedną z przyczyn niepodjęcia interwencji w sprawie właśnie to, że wnioskodawca nie był klientem podmiotu rynku finansowego ${ }^{16}$.

Wymienione w wyżej przywołanym przepisie określenia znajdują się zarówno w krajowych, jaki unijnych aktach prawnych. W dyrektywach europejskich osoby korzystające $z$ usług finansowych, a co za tym idzie chronione przez poszczególne przepisy prawne, określa się poprzez bezpośrednie odwołanie się do nazwy usługi będącej przedmiotem

${ }^{11}$ Tekst jedn. Dz.U. 2020, poz. 1740 ze zm.

12 Tekst jedn. Dz.U. 2021, poz. 275.

${ }^{13}$ Teks jedn. Dz.U. 1997 Nr 78, poz. 483 ze zm.

${ }^{14}$ Tekst jedn. Dz.U. 2021, poz. 162.

15 Tekst jedn. Dz.U. 2020, poz. 2320.

${ }^{16}$ Sprawozdanie z działalności Rzecznika Finansowego w 2020 r. oraz uwagi o stanie przestrzegania prawa i interesów klientów podmiotów rynku finansowego i sprawozdanie z działalności w 2020 r. finansowanej ze środków Funduszu Edukacji Finansowej wraz z informacją o wykorzystaniu środków Funduszu, Warszawa 2021, s. 8. 
danej regulacji: użytkownik ustugi płatniczej, deponent, posiadacz rachunku, beneficjent czy poszkodowany ${ }^{17}$. W krajowej Ustawie z dnia 20 kwietnia 2004 r. o indywidualnych kontach emerytalnych oraz indywidualnych kontach zabezpieczenia emerytalnego ${ }^{18}$ podmiotem zawierającym umowę z instytucją finansową będzie oszczędzajacy zdefiniowany jako osoba fizyczna (art. 2 pkt 3 ustawy) oraz osoby uprawnione, przez które należy rozumieć wskazane przez oszczędzającego osoby, członków jego rodziny oraz spadkobierców (art. 2 pkt 12).

Ponadto obecnie nie tylko prawo wyznacza kategorię, do której osoba jest zaliczana, w pewnych przypadkach może ona dokonać tego samodzielnie. Swoiste novum stanowi przyjęte dyrektywą z dnia 15 maja 2014 r. 2014/65/UE w sprawie rynków instrumentów finansowych ${ }^{19}$ (dyrektywa MiFID II) „subiektywno-merytoryczne kryterium oceny podmiotu statusu (potencjalnego) klienta jako kontrahenta instytucji finansowej"20. Usługobiorca samodzielnie dokonuje wyboru swojego statusu $\mathrm{w}$ relacjach z przedsiębiorcą. Może przybrać jedną z dwóch postaci zdefiniowanych w art. 4 ust. 1 pkt 10 i 11: odpowiednio klienta profesjonalnego i klienta detalicznego.

Ten specyficzny podział uczestników korzystających z usług na rynku finansowym został wdrożony do polskiego porządku prawnego w dwóch ustawach: Ustawie z dnia 27 maja 2004 r. o funduszach inwestycyjnych i zarządzaniu alternatywnymi funduszami inwestycyjnymi ${ }^{21}$ oraz Ustawie z dnia 29 lipca 2005 r. o obrocie instrumentami finansowymi (ustawa o oif $)^{22}$. Artykuł 3 pkt 39b oraz pkt 39c ustawy o oif stanowią o kliencie profesjonalnym i kliencie detalicznym. Do klientów profesjonalnych zalicza się instytucje finansowe (m.in. banki, firmy inwestycyjne, towarowe domy maklerskie), których katalog jest otwarty, przedsiębiorców spełniających określone wymogi dotyczące wielkości kapitału i przychodów oraz inwestorów instytucjonalnych. Pozostałe podmioty są określane mianem klientów detalicznych. Jednocześnie jednak klient detaliczny może być traktowany jako klient profesjonalny. Przydzielenie do tej kategorii następuje na pisemne żądanie podmiotu, które instytucja finansowa akceptuje tylko w przypadku posiadania przez podmiot odpowiedniej

\footnotetext{
${ }^{17}$ A. Nadolska, op. cit., s. 70.

${ }^{18}$ Tekst jedn. Dz.U. 2019, poz. 1808 ze zm.

${ }^{19}$ Dz.Urz. UE, L 173 z 12 VI 2014, s. 349.

${ }^{20}$ A. Nadolska, op. cit., s. 67.

${ }^{21}$ Tekst jedn. Dz.U. 2021, poz. 605 ze zm.

${ }^{22}$ Tekst jedn. Dz.U. 2021, poz. 328 ze zm.
} 
wiedzy i doświadczenia w zakresie ryzykownych inwestycji. Zgodnie z art. 94 ust. 1 pkt 1 lit. c minister właściwy do spraw instytucji finansowych w drodze rozporządzenia określa reguły traktowania klientów jak klientów profesjonalnych lub klientów detalicznych.

W $\S 2$ pkt 15 Rozporządzenia Ministra Finansów z dnia 30 maja 2018 r. w sprawie trybu i warunków postępowania firm inwestycyjnych, banków, o których mowa w art. 70 ust. 2 ustawy o obrocie instrumentami finansowymi, oraz banków powierniczych ${ }^{23}$ posłużono się pojęciem klient, którego zdefiniowano jako osobę fizyczna, osobę prawną lub jednostkę organizacyjną nieposiadającą osobowości prawnej, która zawarła z firmą inwestycyjną lub bankiem umowę o świadczenie usług maklerskich lub z bankiem powierniczym umowę o prowadzenie rachunku papierów wartościowych lub rachunku derywatów.

Powyższe rozporządzenie podtrzymuje koncepcję klienta jako terminu rozumianego bardzo szeroko. Słownik jezzyka polskiego podaje następującą definicję klienta: "osoba kupująca coś w sklepie, korzystająca z usług banku, adwokata itp. lub załatwiająca sprawę w jakiejś instytucji" $^{\prime 2}$. Z praktyki również wiadomo, że instytucje finansowe każdą osobę, która korzysta z ich usług, mianują swoim klientem. Zaś ustawa o RzF wprowadza korektę i do grona klientów zalicza tylko określoną grupę podmiotów - osoby fizyczne korzystające z usług przedsiębiorców finansowych.

Powszechne stosowanie pojęcia klient i odejście od pojęcia konsument w językach prawnym i prawniczym pokazuje bardzo ciekawą tendencję w prawie usług finansowych. Ochrona kliencka zaczyna zastępować ochronę konsumencka, która była uzasadniona przede wszystkim brakiem profesjonalizmu konsumenta - osoby fizycznej niebędącej przedsiębiorcą. Teraz przedsiębiorca, który nie prowadzi działalności w sektorze finansowym, staje się de facto nieprofesjonalistą. Mowa tutaj zwłaszcza o osobach fizycznych prowadzących działalność gospodarczą, które w świetle powyższych przepisów mogą skorzystać z pomocy RzF.

Zatem w przypadku usług finansowych coraz częściej odchodzi się od przyjętych i stosowanych w praktyce przez dziesięciolecia założeń dotyczących klienta przedsiębiorcy: w przypadku klienta - przedsiębiorcy jest podważany jego profesjonalizm, a klientowi - osobie fizycznej nie jest przyznawana zdolność do prawidłowej oceny oferty przedsiębiorcy

${ }^{23}$ Tekst jedn. Dz.U. 2018, poz. 1112.

${ }^{24}$ Zob. Stownik języka polskiego PWN, hasło: klient, https://sjp.pwn.pl/sjp/ klient;2563597.html (dostęp: 3 IX 2021). 
finansowego, dla przykładu „przy ocenie tzw. misselingu w większości przypadków stopień skomplikowania produktów finansowych wyklucza możliwość stosowania modelu przeciętnego konsumenta"25. Określenie przeciętny konsument coraz bardziej traci na znaczeniu w przypadku osób będących stroną umowy o usługi finansowe.

Do wielości używanych w aktach prawnych pojęć dochodzi problem braku uniwersalnego charakteru definicji konsumenta i klienta ${ }^{26}$, na co wskazuje doktryna, a zarazem formułuje własne definicje klienta, na przykład ,jest to nieprofesjonalny uczestnik rynku finansowego, na rzecz którego bank (lub inna instytucja finansowa) świadczy usługi, który odpowiada definicji klienta detalicznego nieposiadającego doświadczenia i wiedzy pozwalającej na podejmowanie właściwych decyzji i oceny związanego z nimi ryzyka"27. E. Rutkowska-Tomaszewska zaznacza dodatkowo, że często używa się różnorodnych określeń na oznaczenie właśnie konsumenta ${ }^{28}$.

Tożsame podejście przedstawiane jest w opracowaniach dotyczących rynku finansowego i ochrony inwestorów „pojęcie [konsumenta] obejmuje inwestora detalicznego będącego osobą fizyczna, która powierza swoje środki firmie inwestycyjnej na rynku pierwotnym lub wtórnym"29.

Jednak praktyka instytucji ochrony konsumentów i fakt, że mamy do czynienia z ustawowymi definicjami w ustawach, skłaniają do spojrzenia na podmiot, któremu instytucje te mogą udzielić ochrony prawnej z perspektywy wyłącznie ustawy, choć tożsame pojęcia występować mogą $w$ innych aktach prawnych czy literaturze, ale mieć całkowicie inne znaczenie.

\section{Analiza kompetencji Rzecznika Finansowego}

Instytucja RzF powstała z dniem wejścia w życie ustawy o RzF, a więc w dniu 11 października 2015 r., RzF „przejął bowiem dotychczasowe kompetencje Rzecznika Ubezpieczonych, przy czym obszar jego kompetencji został rozszerzony na cały rynek finansowy, a zakresem jego interwencji

${ }^{25}$ Cyt. za M. Mamczarek, Ochrona zbiorowych praw i interesów konsumentów, pacjentów oraz pasażerów w transporcie kolejowym, Warszawa 2019, s. 10.

${ }^{26}$ A. Nadolska, op. cit., s. 69.

${ }^{27}$ E. Rutkowska-Tomaszewska, op. cit., s. 35.

${ }^{28}$ Ibidem.

${ }^{29}$ J. Dybiński, Zagadnienia ogólne ochrony inwestora na rynku instrumentów finansowych, w: Prawo instrumentów finansowych, pod red. M. Steca, Warszawa 2016, s. 1295. 
objęto klientów pozostałych sektorów rynku finansowego - bankowego i rynku kapitałowego"30. Jest organem sprawującym ochronę konsumencką w konkretnym obszarze rynku, instytucją szczególną chroniącą interesy konsumenta na rynku usług finansowych. Podstawa jego działania oraz zakres kompetencji zawarte są w ustawie o RzF oraz Rozporządzeniu Ministra Rozwoju i Finansów z dnia 15 lutego 2017 r. w sprawie pozasądowego postępowania przez Rzecznikiem Finansowym ${ }^{31}$.

RzF rozpatruje wnioski w sprawach klientów (tutaj i dalej w rozumieniu ustawy o RzF) podmiotów rynku finansowego. Podstawowym warunkiem wszczęcia postępowania jest uprzednie złożenie reklamacji do podmiotu rynku finansowego, która nie została rozpatrzona zgodnie z żądaniem klienta. Po wszczęciu postępowania Rzecznik może wystąpić do instytucji finansowej o udzielenie informacji lub wyjaśnień, udostępnienie akt oraz dokumentów. W Ustawie z dnia 29 sierpnia $1997 \mathrm{r}$. Prawo bankowe ${ }^{32} \mathrm{w}$ art. 105 pkt 2 lit. wa na bank nałożono obowiązek udzielenia RzF informacji stanowiącej tajemnicę bankową.

Organ podejmuje czynności z urzędu lub na wniosek klienta podmiotu rynku finansowego, organu władzy publicznej lub organizacji konsumenckiej. Może też wszcząć postępowanie sądowe w sprawie dotyczącej nieuczciwych praktyk rynkowych lub wziąć udział w toczącym się już postępowaniu. Wiele zależy tutaj od klienta instytucji finansowej, jedynie za wyrażeniem jego zgody RzF może dołączyć do toczącego się postępowania oraz powziąć informacje o sprawie od instytucji finansowej w jego sprawie. Klient także decyduje, czy będzie brać udział w prowadzonym przy RzF pozasądowym postępowaniu, a także czy jego celem będzie zbliżenie stanowisk stron i/lub przedstawienie stronom propozycji rozwiązania sporu. Natomiast instytucja finansowa ma obowiązek uczestniczyć w tym postępowaniu. RzF stwarza możliwość dialogu pomiędzy klientem a instytucją finansową w postaci wymiany dokumentów oraz żądań. Osobom, które przeprowadzają takiego rodzaju postępowania, RzF udziela upoważnienia i zapewnia, by miały one odpowiednią wiedzę oraz kwalifikacje. W przypadku, gdy cel postępowania nie zostanie osiągnięty, RzF sporządza opinię, która nie ma charakteru aktu wiążącego prawnie, ale może być pomocna dla klienta w postępowaniu cywilnym przed sądem.

${ }^{30}$ A. Jurkowska-Zeidler, Rzecznik Finansowy: nowa instytucja ochrony klienta na rynku ustug finansowych, "Gdańskie Studia Prawnicze" 2017, t. XXXVIII, s. 352.

${ }_{31}$ Dz.U. 2017, poz. 313.

${ }^{32}$ Tekst jedn. Dz.U. 2021, poz. 432 ze zm. 
RzF został wyposażony także w instrument, który jest charakterystyczny "dla organów administracji - możliwość rozstrzygania i nakładania sankcji w postaci administracyjnych kar pieniężnych"33 do wysokości 100000 zł. Zgodnie z art. 32 RzF może w drodze decyzji nałożyć ją na przedsiębiorcę finansowego, który nie stosuje się do przepisów ustawy, m.in. nie określa niezbędnych informacji o składaniu reklamacji albo nie rozpatruje jej w terminie, nie podając przy tym nowego terminu i uzasadnienia zwłoki.

RzF podejmuje również wiele inicjatyw edukacyjnych, które mają na celu wyjaśnienie istoty zadań wykonywanych przez RzF, jego roli, w jaki sposób wykonuje on swoje kompetencje oraz, co jest niezwykle istotne, udziela porad, jak bezpiecznie korzystać z usług finansowych, na co zwracać szczególną uwagę $\mathrm{w}$ kontaktach $\mathrm{z}$ instytucjami finansowymi. Edukuje poprzez dostępne dla szerokiego grona odbiorców webinaria, o których informuje na swojej stronie internetowej, czytelne infografiki na temat pomocy świadczonej przez organ oraz organizację corocznych konferencji naukowych z udziałem Rzecznika Finansowego, na których przedstawiciele nauki oraz prawnicy przedstawiają swoje uwagi na temat ochrony konsumenta usług finansowych.

W doktrynie coraz częściej podkreśla się wagę edukacji konsumenc$k^{3 i e j}{ }^{34}$, pełniącą funkcję prewencyjną w zakresie ochrony konsumenta. Sprawia ona, że do sytuacji konfliktowej pomiędzy klientem a instytucją finansową może nie dojść, zatem nie będą poniesione zbędne nakłady i koszty obciążające zarówno klienta, jak i sądy czy instytucje.

Mimo że w aktach prawnych istnieje wiele powiązań RzF z państwowymi organami władzy publicznej, m.in. RzF może przekazać sprawę do Prezesa UOKiK lub KNF, w doktrynie postuluje się zwiększenie zaangażowania RzF w sprawy podlegające takim instytucjom jak Narodowy Bank Polski czy KNF. Jest to uzasadnione informacja, którą RzF uzyskuje bezpośrednio od klientów rynku finansowego. Mając możliwość analizowania szeregu spraw, zdolny jest do formułowania wniosków mających wymiar systemowy, które następnie powinny "stawać się okresową podstawą oceny działań, dokonywaną przez nadzorcę krajowego rynku finansowego, współpracującego z Rzecznikiem"35.

${ }^{33}$ P. Lissoń, Rzecznik Małych i Średnich Przedsiębiorców: ombudsman czy organ administracji rządowej?, „Ruch Prawniczy, Ekonomiczny i Socjologiczny” 2018, z. 4, s. 69.

${ }^{34}$ D. Cyman, System ochrony klienta na rynku finansowym w Polsce, w: Ochrona konsumenta..., s. 108.

${ }^{35}$ M. Fedorowicz, Nadzór makroostrożnościowy w Polsce, Poznań 2019, s. 61. 


\section{Kierunek zmian prawnych w zakresie instytucji ochrony konsumenta na rynku usług finansowych z uwzględnieniem specyfiki rynku finansowego}

Zauważyć można tendencję do skupiania funkcji mających na celu ochronę interesów konsumentów w jednej instytucji. Odchodzi się od wąskiej specjalizacji organów: tak w 2015 r. Rzecznik Ubezpieczonych stał się RzF, a pięć lat później zaproponowano przeniesienie kompetencji RzF w gestię Prezesa UOKiK.

Tendencja do coraz większego upubliczniania prawa ochrony konsumentów w obszarze usług finansowych ujawniła się w opublikowanym w grudniu 2020 r. projekcie ustawy o rozpatrywaniu reklamacji i sporów klientów podmiotów rynku finansowego oraz o Funduszu Edukacji Finansowej ${ }^{36}$. Zakładał on likwidację Rzecznika Finansowego i przekazanie jego kompetencji Prezesowi Urzędu Ochrony Konkurencji i Konsumentów.

Jednak wymogi, które słusznie zostały wskazane w art. 13 ustawy o Rzeczniku Finansowym (o odpowiedniej wiedzy na temat funkcjonowania rynku finansowego i regulacji prawnych tworzących jego otoczenie oraz o co najmniej siedmioletnim doświadczeniu zawodowym w tym obszarze), nie znalazły odzwierciedlenia w projekcie ustawy. Prezes UOKiK jest organem, który bada wszystkie obszary rynku, a jego organizacja jest dostosowana do innych procedur pracy z konsumentami oraz przedsiębiorcami. Łączenie obu zadań jednocześnie mogłoby sprawiać w praktyce wiele trudności. Obecnie, po pierwszym czytaniu, projekt ustawy został skierowany do dalszych prac podkomisji stałej do spraw instytucji finansowych ${ }^{37}$.

W tym miejscu poszukać należy ratio takiego zabiegu w ustawodawstwie europejskim. Komisja Europejska opublikowała nowy program na rzecz konsumentów z dnia 13 listopada 2020 r. zatytułowany Poprawa odporności konsumentów na potrzeby trwałej odbudowy ${ }^{38}$, przedstawiający wizję polityki ochrony konsumentów na lata 2020-2025. Jednym

${ }^{36}$ Rządowy projekt ustawy o rozpatrywaniu reklamacji i sporów klientów podmiotów rynku finansowego oraz o Funduszu Edukacji Finansowej z 9 XII 2020 r., druk sejmowy nr 834.

${ }^{37}$ Pełny zapis przebiegu posiedzenia Komisji Finansów Publicznych (nr 133) z dnia 10 II 2021 r., https://orka.sejm.gov.pl/zapisy9.nsf/0/57D55EB382A305E3C125868B0048CDAE/\%24File/0097209.pdf (dostęp: 1 IX 2021).

${ }^{38}$ Komunikat Komisji do Parlamentu Europejskiego i Rady, Nowy program na rzecz konsumentów. Poprawa odporności konsumentów na potrzeby trwałej odbudowy, https://eur-lex. 
z pięciu przedstawionych obszarów priorytetowych stała się możliwość dochodzenia roszczeń i egzekwowanie praw konsumentów. Obszar usług finansowych i zjawisko nadmiernego zadłużenia znalazły się w części dokumentu dotyczącej „szczególnych potrzeb konsumentów”, jednak jako środki zaradcze wskazano tylko „doradztwo w zakresie zadłużenia".

Jako że według art. 4 ust. 2 Traktatu o Funkcjonowaniu Unii Europejskiej ${ }^{39}$ obszar ochrony konsumentów należy do kompetencji dzielonych pomiędzy instytucjami unijnymi a państwami członkowskimi, widać zatem, że kwestie instytucjonalne ochrony konsumenta nie są szeroko podnoszone przez Komisję Europejską.

Kluczowym aktem prawnym regulującym materię instytucjonalną jest Rozporządzenie unijne 2017/2394 z dnia 12 grudnia 2017 r. w sprawie współpracy między organami krajowymi odpowiedzialnymi za egzekwowanie przepisów prawa w zakresie ochrony konsumentów i uchylające rozporządzenie (WE) nr 2006/2004 ${ }^{40}$. Regulacje te są istotne przede wszystkim w kontekście unijnym, w większym stopniu dotyczą handlu transgranicznego usługami niż transakcji dokonywanych na rynku krajowym. Rozporządzenie w art. 5 nakłada na państwa członkowskie obowiązek wyznaczenia co najmniej jednego właściwego organu i jednolitego urzędu łącznikowego, którym w Polsce został Prezes UOKiK. Rozporządzenie wyznacza też wymogi, które powinny spełniać takie organy.

Niektóre uwagi dotyczące krajowej sytuacji ochrony konsumentów są przedstawione w preambule Dyrektywy 2019/2161 z dnia 27 listopada 2019 r. w odniesieniu do lepszego egzekwowania i unowocześniania unijnych przepisów dotyczących ochrony konsumenta ${ }^{41}$. Jako wiodące priorytety działań unijnych instytucji wskazano edukację konsumencką oraz efektywne egzekwowanie praw konsumentów i dochodzenie roszczeń. Wskazano brak regulacji krajowych, które w pełni gwarantowałyby skuteczne i proporcjonalne sankcje mogące powstrzymać naruszenia i karać za nie. W tym kontekście takie uprawnienia moga być nadane jedynie organom państwowym (publicznoprawnym, administracyjnym) i im większy będzie ten organ, tzn. im więcej kompetencji będzie

europa.eu/legal-content/PL/TXT/HTML/?uri=CELEX:52020DC0696\&from=PL (dostęp: 28 VI 2021).

${ }^{39}$ Dz.Urz. UE C 326 z 26 X 2012, s. 47.

${ }^{40}$ Dz.Urz. UE L 345 z 27 XII 2017, s. 1.

${ }^{41}$ Dz.Urz. UE L 328 z 18 XII 2019, s. 7. 
posiadał, a co za tym (w założeniu) idzie - kwalifikowanej kadry, tym większy będzie jego autorytet i rola na rynku.

Uzasadnienia faktycznego zmian można doszukiwać się w specyfice rynku finansowego, która sprowadza się do tego, że na ogół podmioty finansowe to potężne instytucje o zasięgu międzynarodowym, zwane konglomeratami, holdingami, koncernami albo grupami kapitałowymi, natomiast definiuje się je jako "skomplikowane organizacje gospodarcze", których „istnienie jest wynikiem integracji międzysektorowej, a także transgranicznej $[\ldots]^{\prime \prime 4}$. Znamienne jest, że "siłą napędową" ich powstania jest wzrost wartości dla akcjonariusza, a tym samym umocnienie pozycji na rynku ${ }^{43}$. Podobne zjawisko występuje na rynku giełdowym. Jak zaznacza J. Dybiński „[...] w wyniku umiędzynarodowiania giełd, giełdy krajowe łączą się lub są przejmowane przez zagraniczne, tworząc nowe spółki lub konglomeraty giełdowe ${ }^{\prime \prime 4}$. Z tej perspektywy uwidacznia się i pogłębia różnica nie tylko pomiędzy pozycją instytucji finansowej a konsumentem na rynku, lecz również pomiędzy krajowym zasięgiem działania pojedynczej instytucji ochrony konsumentów a międzynarodowym zasięgiem działania instytucji finansowej.

Zatem, być może $\mathrm{z}$ tego punktu widzenia, pojawia się pewne uzasadnienie takiego rozszerzania kompetencji instytucji ochrony konsumentów, które oprócz zbiorowych praw konsumentów mają zajmować się ich indywidualnymi sprawami. Chodzić też może o przejrzystość całego systemu, w którym konsument nie będzie zobligowany wyszukiwać odpowiedniej instytucji dla swojej konkretnej sprawy, ale będzie obowiązywała reguła tzw. „jednego okienka”.

\section{Analiza kompetencji Prezesa Urzędu Ochrony Konkurencji i Konsumentów}

Organem krajowym, którego zadania skupiają się w dwóch obszarach: przeciwdziałanie nadmiernym koncentracjom przedsiębiorców oraz ochrona konsumentów, jest Prezes UOKiK.

Podstawę działania Prezesa UOKiK stanowi Ustawa z dnia 16 lutego 2007 r. o ochronie konkurencji i konsumentów. Ustawa chroni konsumenta poniekąd pośrednio, gdyż głównym celem działań organu jest

\footnotetext{
${ }^{42}$ M. Iwanicz-Drozdowska, Konglomeraty finansowe, „Bank i Kredyt” 2007, nr 6, s. 3.

${ }^{43}$ Ibidem, s. 6.

${ }^{44}$ J. Dybiński, op. cit., s. 1315.
} 
zapewnienie uczciwej konkurencji na rynku, choć „ostatecznym celem polityki konkurencji jest ochrona długofalowych interesów konsumentów" ${ }^{\prime \prime}$. Akt prawny określa kompetencje i zadania tego organu. Przepisy ustawy stosowane są tylko i wyłącznie w przypadkach występujących nieprawidłowości w relacjach prawnych konsumenta z przedsiębiorcą.

W kontekście zadań Prezesa Urzędu i możliwości jego ingerencji $\mathrm{w}$ działanie przedsiębiorstw istotna jest przesłanka istnienia interesu publicznego $w$ badanych naruszeniach ${ }^{46}$. Nie jest ona definiowana na gruncie ustawy, a (zgodnie z orzecznictwem) oceniana w kontekście pojedynczej sprawy ${ }^{47}$. Ustawa zaś wiąże tę przesłankę z istnieniem praktyk, które mają odczuwalny wpływ na konkurencję rynkową ${ }^{48}$. Dobro publiczne jest nadrzędną wartością dla prawa administracyjnego ${ }^{49}$, zostało wyrażone również w zastosowanej w ustawie formule o ochronie zbiorowych interesów konsumentów.

Artykuł 23b ustawy uokik stanowi o szczególnej kompetencji Prezesa UOKiK, jaką jest wydawanie decyzji, na mocy której wzorzec umowny jest uznawany za niedozwolony. Wskutek tego naruszenia Prezes Urzędu może podejmować decyzje bardzo dotkliwe dla przedsiębiorców: 1) uznać w decyzji postanowienia wzorca umowy za niedozwolone i zakazać jego wykorzystywania, 2) nałożyć na przedsiębiorcę w decyzji karę pieniężną do $10 \%$ obrotu osiągniętego w roku obrotowym poprzedzającym rok nałożenia kary, 3) określić w decyzji środki konieczne do usunięcia skutków stosowania postanowień niedozwolonych, 4) nakazać publikacji decyzji, także tej nieprawomocnej ${ }^{50}$. Istotny jest też krąg podmiotów, których obejmuje decyzja wydana przez Prezesa UOKiK, zgodnie bowiem $\mathrm{z}$ art. 23d jest ona skuteczna zarówno wobec przedsiębiorcy, który zastosował niedozwoloną klauzulę, jak i wszystkich konsumentów, których dotyczył rozpatrywany wzorzec.

W art. 24 ust. 2 ustawy uokik przykładowo wskazano, jakie praktyki klasyfikowane są jako naruszające zbiorowe interesy konsumentów.

\footnotetext{
${ }^{45}$ A. Stawicki, E. Stawicki, Ustawa o ochronie konkurencji i konsumentów. Komentarz, Warszawa 2016, s. 35.

${ }^{46}$ T. Skoczny, Ustawa o ochronie konkurencji i konsumentów. Komentarz, Legalis, komentarz do art.1, n.b. 83.

${ }^{47}$ Ibidem, Legalis, komentarz do art.1, n.b. 47.

${ }^{48}$ Ibidem, Legalis, komentarz do art.1, n.b. 41.

${ }^{49}$ R. Hauser, Stosunek administracyjnoprawny, w: Instytucje prawa administracyjnego. System Prawa Administracyjnego, t.1, pod red. R. Hausera, Z. Niewiadomskiego, A. Wróbla, Warszawa 2015, s. 199 i n., Legalis.

${ }^{50}$ A. Stawicki, E. Stawicki, op. cit., s. 587.
} 
Szczególnie ważnym z punktu widzenia badanej materii jest pkt 4 bezpośrednio dotyczący usług finansowych i odwołujący się do praktyki misselingu, który polega na przedstawieniu konsumentowi takiej oferty, która nie odpowiada zapotrzebowaniu klienta lub proponowaniu nabycia usług niezgodnie $\mathrm{z}$ ich charakterem.

Prezesowi Urzędu udzielono także kompetencji w Ustawie z dnia 23 września 2016 r. o pozasądowym rozwiązywaniu sporów konsumenckich $^{51}$ - zgodnie z art. 20 tej ustawy prowadzi on rejestr podmiotów uprawnionych do rozstrzygania sytuacji konfliktowych w tym trybie. Art. 43 wskazuje także na zadanie polegające na monitorowaniu, czy podmioty spełniają warunki niezbędne do pozasądowego rozstrzygania sporów i analizowaniu sprawozdań z ich działalności.

Według art. 31 ustawy uokik Prezes UOKiK między innymi wydaje decyzje w sprawach o uznanie postanowień wzorca umowy za niedozwolone oraz w sprawach praktyk naruszających zbiorowe interesy konsumentów, przygotowuje projekty rządowej polityki konsumenckiej, opracowuje i wydaje publikacje oraz programy edukacyjne popularyzujące wiedzę o ochronie konkurencji i konsumentów, oraz występuje do przedsiębiorców w sprawach z zakresu ochrony konkurencji i konsumentów.

Prezes UOKiK ma więcej możliwości oddziaływania na przedsiębiorcę. Przede wszystkim dlatego, że jest to organ administracji, który reprezentuje władztwo państwowe ${ }^{52}$. Decyzja administracyjna jest podstawowym instrumentem stosowanym przez Urząd. Warto zwrócić uwagę na fakt, że jest to relacja organ administracji-przedsiębiorca. Zatem konsument nie ma w tym przypadku statusu strony i nie może wpływać na przebieg postępowania czy odwoływać się od decyzji ${ }^{53}$.

Klient instytucji finansowej może wnieść do organu skargę w trybie określonym w art. 63 Ustawy z dnia 14 czerwca 1960 r. Kodeks postępowania administracyjnego ${ }^{54}$. Jej wniesienie nie oznacza jednak, że Prezes UOKiK rozpatrzy przedmiotową sprawę. W gestii organu jest podjęcie decyzji, czy charakter sprawy uzasadnia jego interwencję. Artykuł 49 ustawy uokik wyraźnie wskazuje, że wymienione postępowania wszczynane są z urzędu. „Organ antymonopolowy ma bowiem

\footnotetext{
${ }^{51}$ Tekst jedn. Dz.U. 2016, poz. 1823.

${ }^{52}$ R. Hauser, op. cit., s. 202.

${ }^{53}$ Ibidem.

${ }^{54}$ Tekst jedn. Dz.U. 2021, poz. 735 ze zm.
} 
koncentrować się na najpoważniejszych naruszeniach konkurencji"55, stąd wynika zasadność braku obowiązku rozpatrywania wszystkich wpływających do organu spraw. Istnieje również możliwość wniesienia innego pisma regulowanego przez ustawę uokik - zawiadomienia. Tak samo jak w przypadku skargi podjęcie działań przez Prezesa UOKiK jest fakultatywne.

\section{Podsumowanie}

Z powyższych rozważań wynika, że z pomocy Rzecznika Finansowego mogą skorzystać nie tylko - jak w przypadku Prezesa UOKiK - osoby korzystające z usługi finansowej niezwiązanej z prowadzoną przez nich działalnością gospodarczą, lecz również osoby fizyczne, które nabywają usługę finansową w celu wykonywania tejże działalności.

Negatywnie należy ocenić wielość kategorii podmiotów chronionych na płaszczyznach różnych ustaw. Szczególnie po nowelizacji przepisów cywilnoprawnych osoby fizyczne prowadzące działalność gospodarczą w pewnych przypadkach są chronione i mogą uzyskać wsparcie od instytucji ochrony konsumentów, a w niektórych sytuacjach ta ochrona nie jest im udzielana (nie udzielono tej grupie również uprawnień przysługujących wyłącznie konsumentom - w cywilistycznym znaczeniu - w zakresie usług finansowych nabywanych za pomocą środków porozumiewania się na odległość). Należy zauważyć, że jedną z grup szczególnego ryzyka są właśnie przedsiębiorstwa jednoosobowe. Spory dotyczące nabytych przez nie usług finansowych mających związek z prowadzoną przez nie działalnością, nie będą mogły być przedmiotem rozpatrywanych przez Prezesa UOKiK spraw. Wydaje się jednak, że ich zbiorowe interesy na rynku finansowym nie powinny zostać pominięte. Ochrona zbiorowa wydaje się tutaj efektywniejsza i bardziej pożądana niż ochrona indywidualna.

Uzasadnieniem takiego podejścia może być fakt, że przedsiębiorcy mają więcej możliwości łączenia się, na przykład w ramach własnej grupy branżowej, w grupy mogące dostatecznie efektywnie reprezentować swoje interesy, ale w niektórych segmentach rynku, zwłaszcza kapitałowym, inwestorzy nie mogą należeć do dostatecznie wielkiej oraz wpływowej grupy podmiotów w stosunku do instytucji finansowej.

${ }^{55}$ Ustawa o ochronie konkurencji i konsumentów. Komentarz, pod red. K. Kohutka, M. Sieradzkiej, Warszawa 2014, s. 774. 
Obecnie ustawodawca, w tym europejski, dokonuje wyznaczenia podmiotów chronionych na rynkach w trojaki sposób: 1) wprowadzając określenia objęte definicją, np. konsument, klient, 2) obejmując dotychczasowymi przepisami podmioty o cechach innych niż zdefiniowany podmiot poprzez ich wymienienie, 3) pozostawiając podmiotowi decyzję do wyznaczenia potrzeby objęcia swojego stosunku z przedsiębiorcą szczególną ochroną prawną.

Temat ochrony konsumenta na rynku finansowym i instytucji stojących na straży jego interesów jest ciekawy przede wszystkim ze względu na swoją interdyscyplinarność (badania powinny być prowadzone na styku prawa i ekonomii), a także nieustannie zmieniającą się praktykę. Dodatkowym czynnikiem, który w najbliższym czasie może spowodować wzmożenie prac legislacyjnych, jest coraz większe zainteresowanie bardziej ryzykownymi usługami finansowymi w postaci lokaty kapitału na rynku giełdowym przez osoby, które "wykorzystują rynek kapitałowy w celu pomnożenia swojego majątku, szukając alternatyw np. wobec niskoprocentowych lokat bankowych"56.

\section{CONTEMPORARY TRENDS IN CONSUMER PROTECTION ON THE FINANCIAL SERVICES MARKET AND THE REGULATIONS OF CONSUMER PROTECTION INSTITUTIONS: THE FINANCIAL OMBUDSMAN AND PRESIDENT OF THE OFFICE OF COMPETITION AND CONSUMER PROTECTION}

\section{S u m mary}

The article deals with some issues related to consumer (client) protection on the financial market. Legal regulations constantly change in this area. New regulations are introduced, which makes the subject of consumer protection very topical and important, especially with many accompanying transactions on the financial market. The multiplicity of legal acts and the influence of European legislation, especially EU regulations, can lead to many misunderstandings in terms of terminology. An attempt was made to clarify the concepts of consumer and client on the basis of Polish legislation. According to numerous amendments to the regulation, the entities on the market using financial services should make efforts to conduct a correct assessment of its legal situation and the possibility of using the help of institutions. The range of protected entities differ depending on the legal act that is analyzed. The author draws attention to the ways in which the legislator created a definition of a protected entity and the areas in which it provides legal protection. The analysis also includes legal provisions concerning the competences of institutions performing consumer protection functions: the Financial Ombudsman and the President of

\footnotetext{
${ }^{56}$ J. Dybiński, op. cit., s. 1296.
} 
the Office of Competition and Consumers, which is a body specializing in individual consumer matters, and a public administration body. Their competences and roles, which overlap in certain areas, have been the subject of lively discussion for a time. This was due to the proposed draft act of December 2020, the provisions of which abolished the institution of the Financial Ombudsman, and transferred his competences to the President of the Office of Competition and Consumer Protection. The paper presents the direction of legal changes in the institutional area of consumer protection of financial services, the ratio of such actions, as well as the outlined European legislator's vision of adequate consumer protection.

Keywords: consumer - client - consumer protection - financial market - institutional consumer protection

\section{LITERATURA}

Cyman D., System ochrony klienta na rynku finansowym w Polsce, w: Ochrona konsumenta na polskim i międzynarodowym rynku finansowym, pod red. J. Monkiewicza, E. Rutkowskiej-Tomaszewskiej, Warszawa 2019.

Dybiński J., Zagadnienia ogólne ochrony inwestora na rynku instrumentów finansowych, w: Prawo instrumentów finansowych, pod red. M. Steca, Warszawa 2016.

Fedorowicz M., Nadzór makroostrożnościowy w Polsce, Poznań 2019.

Hauser R., Stosunek administracyjnoprawny, w: Instytucje prawa administracyjnego. System Prawa Administracyjnego, t. 1, pod red. R. Hausera, Z. Niewiadomskiego, A. Wróbla, Warszawa 2015, Legalis.

Iwanicz-Drozdowska M., Konglomeraty finansowe, „Bank i Kredyt” 2007, nr 6.

Jurkowska-Zeidler A., Rzecznik Finansowy: nowa instytucja ochrony klienta na rynku ustug finansowych, "Gdańskie Studia Prawnicze" 2017, t. XXXVIII.

Lissoń P., Rzecznik Małych i Średnich Przedsiębiorców: ombudsman czy organ administracji rzadowej?, "Ruch Prawniczy, Ekonomiczny i Socjologiczny” 2018, z. 4.

Łętowska E., Prawo umów konsumenckich, Warszawa 2002.

Mamczarek M., Ochrona zbiorowych praw i interesów konsumentów, pacjentów oraz pasażerów w transporcie kolejowym, Warszawa 2019.

Nadolska A., Konsument $i$ klient na rynku ustug finansowych. Problem zakresu podmiotowego ochrony na rynku finansowym, w: Ochrona konsumenta na polskim i międzynarodowym rynku finansowym, pod red. J. Monkiewicza, E. Rutkowskiej-Tomaszewskiej, Warszawa 2019.

Rutkowska-Tomaszewska E., Ochrona prawna klienta na rynku usług bankowych, Warszawa 2013.

Sieradzka M., Pozew grupowy jako instrument prywatnoprawnej ochrony interesów konsumentów z tytułu naruszenia regut konkurencji, Warszawa 2012.

Skoczny T., Ustawa o ochronie konkurencji i konsumentów. Komentarz, Legalis.

Stawicki A., Stawicki E., Ustawa o ochronie konkurencji i konsumentów. Komentarz, Warszawa 2016.

Ustawa o ochronie konkurencji i konsumentów. Komentarz, pod red. K. Kohutka, M. Sieradzkiej, Warszawa 2014. 
